Original Article

\title{
DEVELOPMENT AND VALIDATION OF STABILITY INDICATING RP-HPLC METHOD FOR THE SIMULTANEOUS ESTIMATION OF ETHINYL ESTRADIOL AND GESTODENE IN BULK AND PHARMACEUTICAL DOSAGE FORMS
}

\section{SUCHITRA ${ }^{1}$, BATTU SATYANARAYANA ${ }^{2 *}$}

1Department of Pharmaceutical Analysis and Quality Assurance, University College of Technology, Osmania University, Hyderabad, Telangana, India, ${ }^{2}$ Department of Chemistry, University College of Science, Osmania University, Hyderabad, Telangana, India

"Email: satyambchem@yahoo.co.in

Received: 26 Mar 2021, Revised and Accepted: 18 May 2021

\section{ABSTRACT}

Objective: The principal objective of this study is to develop and validate a simple, new, fast, selective, precise, and economic stability-indicating the RP-HPLC method for the simultaneous estimation of Ethinyl estradiol and Gestodene in a bulk and pharmaceutical dosage form.

Methods: The present method was developed and validated on a Waters HPLC system using Phenomenex Gemini C18(250 mm $\times 4.6 \mathrm{~mm}$ i.d., $5 \mu \mathrm{m}$ particle size) column and mobile phase composition of phosphate buffer: Acetonitrile $(75: 25 \mathrm{v} / \mathrm{v})$ and the pH was adjusted to 3.6 using dilute orthophosphoric acid. The system was regulated at $1.0 \mathrm{ml} / \mathrm{min}$ flow rate at $237 \mathrm{~nm}$ UV detection.

Results: The two drugs Ethinyl Estradiol and Gestodene, were eluted at $1.788 \mathrm{~min}$ and $3.475 \mathrm{~min}$ retention time, respectively. The analytical parameters such as accuracy, precision, linearity, LOD, LOQ, ruggedness, and robustness were used for validating the developed method according to International Conference on Harmonisation [ICH] guidelines. Linearity was exhibited over the concentration range of $10-50 \mu \mathrm{g} / \mathrm{ml}$ and $25-$ $125 \mu \mathrm{g} / \mathrm{ml}$ for Ethinyl Estradiol and Gestodene, respectively. The method revealed the Limit of Detection and Quantitation values for Ethinyl Estradiol and Gestodene were $1.399 \mu \mathrm{g} / \mathrm{ml}, 3.909 \mu \mathrm{g} / \mathrm{ml}$ and $4.24 \mu \mathrm{g} / \mathrm{ml}, 11.85 \mu \mathrm{g} / \mathrm{ml}$, respectively. The stress testing was carried out to give rise to degradation products by exposing the drugs to acid, alkali, thermal, oxidative, photolytic, and hydrolytic degradation. The obtained data showed that the content of Active pharmaceutical ingredients and the degradation products were successfully separated without any interference, which confirmed the stability-indicating nature of the developed method.

Conclusion: The new, simple, rapid, selective, precise, and economic stability-indicating RP-HPLC method has been successfully developed and validated. It can be satisfactorily applied for the periodic laboratory quantitative estimation of Ethinyl Estradiol and Gestodene in formulations and active pharmaceutical ingredients.

Keywords: RP-HPLC, Method development, Method validation, Forced degradation studies

(C) 2021 The Authors. Published by Innovare Academic Sciences Pvt Ltd. This is an open access article under the CC BY license (https://creativecommons.org/licenses/by/4.0/) DOI: https://dx.doi.org/10.22159/ijpps.2021v13i7.41615. Journal homepage: https://innovareacademics.in/journals/index.php/ijpps.

\section{INTRODUCTION}

Ethinyl Estradiol is chemically $(8 R, 9 S, 13 S, 14 S, 17 R)$-17-ethynyl-13methyl-7,8,9,11,12,14,15,16-octahydro-6H-cyclopenta[a] phenanthrene -3,17-diol [fig. 1], an estrogen drug is used widely in birth control pills in combination with progestins. It is used to treat menopausal symptoms, gynecological disorders, and certain hormone-sensitive cancers [1]. Ethinyl estradiol binds to the estrogen receptor complex, enters the nucleus, and activates the DNA transcription process. It prevents ovulation by decreasing luteinizing hormone, which in turn decreases endometrial vascularization and decreases gonadotrophic hormone. In epididymal tissue, it lowers testosterone levels and prevents prostatic cancer by inhibiting the 5-alpha reductase enzyme. Along with cancer treatment, it is also used for osteoporosis [2].<smiles>C#C[C@@]1(O)CC[C@@H]2c3ccc(O)cc3CC[C@@H]2CC1</smiles>

Fig. 1: Chemical structure of Ethinyl estradiol decahydrocyclopenta[a]phenanthene-3-one [fig. 2], a progestogen hormonal contraceptive used in birth control pills and also used in menopausal hormone therapy [3]. It inhibits growth hormone release from the pituitary gland and suppresses ovulation. It also disrupts fertilization and inhibits implantation [4]

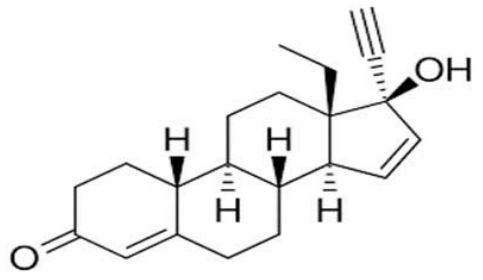

Fig. 2: Chemical structure of gestodene

Femovan tablet has $0.03 \mathrm{mg}$ of Ethinyl estradiol and $0.075 \mathrm{mg}$ of Gestodene as active pharmaceutical ingredients. This combination drug is used for contraception and in the treatment of irregular periods. This drug helps to prevent the release and fertilization of the egg. It is also used to treat ovarian cancer.

From the literature survey, it was revealed that several methods like RP-HPLC [5, 6], UPLC/MS-MS [7], and stability-indicating RP-HPLC [8] methods are described for the quantitative determination of Ethinyl estradiol and Gestodene and Ethinyl estradiol and 
drospirenone [9] in combination form. But the published stabilityindicating method's total analysis time was 65 min which takes more time for analysis and consumes more mobile phase thus becomes expensive. Therefore, it felt necessary to develop and validate a new, rapid, and economic stability-indicating RP-HPLC method, which can be successfully applied for the regular laboratory analysis of Ethinyl estradiol and Gestodene drugs.

\section{MATERIALS AND METHODS}

\section{Chemicals and reagents}

The standard drugs of Ethinyl estradiol and Gestodene were collected as gift samples from Sura labs, Hyderabad. The commercial tablet dosage form FEMOVAN containing $0.03 \mathrm{mg}$ of Ethinyl estradiol and $0.075 \mathrm{mg}$ of Gestodene, marketed by Bayer Zydus Pharma Ltd., was procured from a local pharmacy. Acetonitrile (HPLC grade), Methanol (HPLC grade), water (HPLC grade), and orthophosphoric acid used for the preparation of the mobile phase were a product of Merck.

\section{Instrument used}

The present method was quantitatively estimated on a Waters Alliance 2695 separation module HPLC system, and data processing was done using Empower 2 software. The eluates were monitored at $237 \mathrm{~nm}$ by 996 Photo-diode array detectors. Sonication's dissolution and degassing of the solvents and the mobile phase were achieved on Labman digital ultra sonicator. The $\mathrm{pH}$ of the solution was adjusted by using a Lab India pH meter.

\section{Methods}

\section{Chromatographic conditions}

The simultaneous estimation was achieved on Phenomenex Gemini C18(250 $\mathrm{mm} \times 4.6 \mathrm{~mm}$ i. d, $5 \mu \mathrm{m}$ particle size) column with mobile phase composition of phosphate buffer and acetonitrile $(75: 25 \mathrm{v} / \mathrm{v}$, $\mathrm{pH}$ 3.6) adjusted to a flow rate of $1.0 \mathrm{ml} / \mathrm{min}$ for a total $8 \mathrm{~min}$ run time. The eluates were monitored at $237 \mathrm{~nm}$ by a Photo-diode array detector, and the two drugs Ethinyl Estradiol and Gestodene were eluted at $1.788 \mathrm{~min}$ and $3.475 \mathrm{~min}$ retention time, respectively.

\section{Preparation of stock and working stock solutions}

An accurately weighed $10 \mathrm{mg}$ of Ethinyl Estradiol and Gestodene standard drugs were dissolved in $10 \mathrm{ml}$ of mobile phase, sonicated, and filtered. Further prepared $20 \mu \mathrm{g} / \mathrm{ml}$ and $50 \mu \mathrm{g} / \mathrm{ml}$ concentration working stock solutions of Ethinyl Estradiol and Gestodene respectively, mixed thoroughly, sonicated, and filtered through $0.45 \mu$ membrane filter. Introduced the samples into the HPLC system, recorded the chromatograms, and noted the best-optimized conditions to proceed for validation as per ICH guidelines.

\section{Preparation of sample solution}

Femovan tablets (containing $0.03 \mathrm{mg}$ Ethinyl estradiol and $0.075 \mathrm{mg}$ Gestodene) were taken and crushed in a mortar using a pestle. An equivalent amount of $10 \mathrm{mg}$ of tablet powder was weighed and dissolved in the diluent, diluted to volume, mixed thoroughly, sonicated, and filtered. Injected the sample in triplicates and calculated the $\%$ assay.

\section{Method validation}

As per ICH guidelines $[10,11]$, the parameters checked for method validation are Accuracy, precision, linearity, LOD, LOQ, specificity, and robustness [12-14].

\section{System suitability}

For evaluating the system suitability, the mixed working standard solution of Ethinyl Estradiol and Gestodene was injected five times into the HPLC system, recorded the chromatograms, measured the areas, and calculated the \% RSD for all five injections in HPLC.

\section{Linearity}

The Linearity of the method was determined by plotting the standard curve in the concentration range of $10-50 \mu \mathrm{g} / \mathrm{ml}$ and $25-$ $125 \mu \mathrm{g} / \mathrm{ml}$ for Ethinyl Estradiol and Gestodene, respectively. The peak areas were noted by injecting each level into the chromatographic system. Plotted a calibration curve of analyte response versus concentration, and by linear regression analysis, the correlation coefficient was calculated.

\section{Accuracy}

For evaluating the method's accuracy, added a pre-analyzed sample solution of $20 \mu \mathrm{g} / \mathrm{ml}$ of Ethinyl estradiol and $50 \mu \mathrm{g} / \mathrm{ml}$ of Gestodene to a known amount of standard solution of Ethinyl Estradiol $(10,20$, and $30 \mu \mathrm{g} / \mathrm{ml}$ ) and Gestodene $(25,50$ and $75 \mu \mathrm{g} / \mathrm{ml}$ ) respectively. All the solutions were prepared and injected in triplicates. Recorded the chromatograms and measured the peak responses. Calculated the Amount found and Amount added for Ethinyl Estradiol and Gestodene and calculated the individual recovery and mean recovery values.

\section{Precision}

The developed method's precision was evaluated by Intra-assay precision and Intermediate Precision.

\section{Intra-day precision}

The repeatability of the method was determined by introducing the standard solution containing $20 \mu \mathrm{g} / \mathrm{ml}$ of Ethinyl Estradiol and $50 \mu \mathrm{g} / \mathrm{ml}$ of Gestodene for five replicate injections, noted the areas on the same day under unchanged operating conditions over a short period and calculated the \% RSD.

\section{Intermediate precision}

The intermediate precision of the method was evaluated by injecting the standard solution containing $20 \mu \mathrm{g} / \mathrm{ml}$ and $50 \mu \mathrm{g} / \mathrm{ml}$ of Ethinyl Estradiol and Gestodene, respectively, for five times. Measured the areas and calculated the \%RSD for the five replicate injections on different days under unchanged operating conditions.

\section{Robustness}

The robustness of the developed method was evaluated by deliberate variations in flow rate and mobile phase organic composition.

\section{Effect of the slight change in flow rate}

Examined the solution at $0.9 \mathrm{ml} / \mathrm{min}$ and $1.1 \mathrm{ml} / \mathrm{min}$ rather than 1.0 $\mathrm{ml} / \mathrm{min}$, under unchanged operating conditions. $20 \mu \mathrm{l}$ of the mixed standard solution was injected, recorded the chromatograms, and compared with an optimized chromatogram.

\section{Effect of the slight change of percent organic mobile phase}

The sample was analyzed by varying the percentage of organic mobile phase composition in the ratio of 70:30, 80:20 instead of 75:25, under identical conditions. Injected into the HPLC, recorded the chromatograms and compared with an optimized chromatogram.

\section{Detection limit}

The Ethinyl estradiol and Gestodene LOD values were quantitated by using the formula-

$$
\mathrm{LOD}=3.3 \times \sigma / \mathrm{S}
$$

Where,

$\sigma=$ Standard deviation of the intercept $S=$ Slope of the calibration curve

\section{Limit of quantitation}

The quantitation limit of an analyte in the samples was quantified by using the formula-

$$
\mathrm{LOQ}=10 \times \sigma / \mathrm{S}
$$

Where,

$\sigma=$ Standard deviation of the response $S=$ Slope of the calibration curve

\section{Forced degradation studies}

According to the ICH guidelines, stress testing was carried out upon exposure to extreme stress conditions of acid, base, peroxide, 
thermal, UV, and hydrolytic degradation. Later studied the main peak of the drug for peak purity by calculating the percentage of degraded amount and percentage of the active amount.

\section{Acid degradation}

Added $1 \mathrm{ml}$ of $2 \mathrm{~N} \mathrm{HCl}$ to $1 \mathrm{ml}$ of Ethinyl estradiol and Gestodene stock solutions and refluxed at $60^{\circ} \mathrm{C}$ for 30 min. Later $2 \mathrm{~N} \mathrm{NaOH}$ was added to neutralize the solutions and diluted to volume to obtain $20 \mu \mathrm{g} / \mathrm{ml}$ and $50 \mu \mathrm{g} / \mathrm{ml}$ solutions, respectively. Cooled the solutions to room temperature and filtered. Injected the sample into the HPLC system and recorded the chromatograms.

\section{Alkaline degradation}

Added $1 \mathrm{ml}$ of $2 \mathrm{~N}$ sodium hydroxide to $1 \mathrm{ml}$ of Ethinylestradiol and Gestodene stock solutions, refluxed at $60^{\circ} \mathrm{C}$ for $30 \mathrm{~min}$. Later, $1 \mathrm{ml}$ of $2 \mathrm{~N} \mathrm{HCl}$ was added for neutralization and diluted to volume to obtain $20 \mu \mathrm{g} / \mathrm{ml}$ and $50 \mu \mathrm{g} / \mathrm{ml}$ solutions, respectively. Cooled and then filtered through a $0.45 \mu \mathrm{m}$ membrane filter. Injected into the HPLC system and recorded the chromatograms.

\section{Oxidation degradation}

Added $1 \mathrm{ml}$ of $20 \%$ Hydrogen peroxide to $1 \mathrm{ml}$ of Ethinylestradiol and Gestodene stock solutions and kept for $30 \mathrm{~min}$ at $60^{\circ} \mathrm{C}$. Later diluted to volume to obtain $20 \mu \mathrm{g} / \mathrm{ml}$ and $50 \mu \mathrm{g} / \mathrm{ml}$ solution. Cooled and filtered using $0.45 \mu \mathrm{m}$ membrane filter. Injected the sample into the HPLC system and recorded the chromatograms.

\section{Dry heat degradation}

$1 \mathrm{ml}$ of standard drug solution was kept in an oven for six h at $60{ }^{\circ} \mathrm{C}$ later, diluted to final volume to obtain $20 \mu \mathrm{g} / \mathrm{ml}$ and $50 \mu \mathrm{g} / \mathrm{ml}$ solutions Ethinyl estradiol and Gestodene respectively. Cooled and filtered using $0.45 \mu \mathrm{m}$ membrane filter. Injected into the HPLC system and recorded the chromatograms.

\section{Photodegradation}

For this study, the stock solutions were exposed to UV light for $1 \mathrm{~d}$ or 200Watt-hm-2 in a photostability chamber and later diluted to volume to obtain $20 \mu \mathrm{g} / \mathrm{ml}$ and $50 \mu \mathrm{g} / \mathrm{ml}$ solutions of Ethinyl estradiol and Gestodene, respectively, filtered through a $0.45 \mu \mathrm{m}$ membrane filter. Injected the solutions into the HPLC system and recorded the chromatograms.

\section{Water degradation studies}

Added $1 \mathrm{ml}$ of distilled water to $1 \mathrm{ml}$ of stock solution of Ethinyl estradiol and Gestodene and kept aside at $60{ }^{\circ} \mathrm{C}$ for $30 \mathrm{~min}$. Later, diluted to volume to obtain $20 \mu \mathrm{g} / \mathrm{ml}$ and $50 \mu \mathrm{g} / \mathrm{ml}$ solutions of Ethinyl estradiol and Gestodene, respectively. Filtered the solutions and injected the mixed standard into the HPLC system, and recorded the chromatograms.

\section{RESULTS AND DISCUSSION}

\section{Method development}

For developing the present method, various columns like Symmetry and Zodiac columns were tried. But finally, Phenomenex Gemini $\mathrm{C} 18(25 \times 0.46 \mathrm{~cm}, 5 \mu \mathrm{m})$ was confirmed to be optimal since all the parameters are within the acceptance criteria like resolution, peak symmetry, and theoretical plates. Various mobile phases tried were water: methanol, Water: Acetonitrile, Phosphate buffer: Methanol, Phosphate buffer: Acetonitrile by varying proportions and at last, the Phosphate buffer: Acetonitrile $(75: 25 \mathrm{v} / \mathrm{v})$ and the $\mathrm{pH}$ was adjusted to 3.6 using dilute orthophosphoric acid by maintaining the system at $1.0 \mathrm{ml} / \mathrm{min}$ flow rate at $237 \mathrm{~nm}$ UV detection was finalized as optimal. The optimized chromatogram of Ethinyl estradiol and Gestodene was displayed in fig. 3 and resulted in table 1.

In comparison to the previously reported methods $[5,8]$, the retention times of Ethinyl estradiol and Gestodene were observed to be more and required more analysis time for quantification. But the present established method requires lesser analysis time and consumes lesser solvents showing retention times of Ethinyl estradiol and Gestodene at $1.788 \mathrm{~min}$ and $3.475 \mathrm{~min}$, which is more advantageous in pharmaceutical industries. This revealed that the developed method could be suitably applied for routine laboratory analysis.

\section{Method validation}

\section{System suitability}

All the efficiency parameters like theoretical plates were observed to be more than 7000 for Ethinyl estradiol and Gestodene drugs. The peak tailing was not more than 2.0. The \%RSD for the five replicate injections was not more than 2.0 and ensured that the entire testing system and chemicals used could generate an accurate and precise result by showing all the efficiency parameters within the specified limits. Reported the results in Tables 2 and 3.

\section{Linearity}

The proposed method was confirmed to be linear in the concentration range of $10-50 \mu \mathrm{g} / \mathrm{ml}$ and $25-125 \mu \mathrm{g} / \mathrm{ml}$ for Ethinyl Estradiol and Gestodene, respectively, showing a correlation coefficient of 0.999 , which was analyzed by linear regression analysis. The results proved that the analyte response is proportional to the analyte concentration in the selected concentration range. The calibration graphs of Ethinyl Estradiol and Gestodene are depicted in fig. 4 and fig. 5 and data in Tables 4 and 5, respectively.

\section{Accuracy}

The mean recovery values obtained at 50\%, 100\%, and 150\% levels are $99.84 \%$ and $99.92 \%$ for Ethinyl estradiol and Gestodene, respectively, which are within the acceptance criteria. Thus, it confirmed the method's accuracy and reported the results in Tables 6 and 7.

\section{Precision}

The obtained \%Relative standard deviation of intra-day precision and intermediate precision of Ethinyl estradiol and Gestodene was found to be not more than 2.0, which is within the acceptance criteria, indicating that the developed method is precise. Reported the measured results of intra-day precision in Tables 8,9 and intermediate precision in Tables 10,11, 12, and 13.

\section{Robustness}

The results revealed that the method is robust upon slight changes in flow rate conditions and even by the $\pm 5 \%$ organic phase for Ethinyl estradiol. For Gestodene, upon decreasing the \%organic phase, the retention time was more, and retention time was less for more \%organic phase. There was no significant change in resolution, asymmetry, and plate count. Reported observed results in Tables 14 and 15.

\section{Limit of detection and limit of quantitation}

Calculated the LOD and LOQ using the standard deviation of intercepts and slope of the calibration curve. The measured detection limit and quantitation limit was found to be $1.399 \mu \mathrm{g} / \mathrm{ml}$ and $4.242 \mu \mathrm{g} / \mathrm{ml}$ for Ethinyl estradiol and $3.909 \mu \mathrm{g} / \mathrm{ml}$ and $11.848 \mu \mathrm{g} / \mathrm{ml}$ for Gestodene, respectively. Thus, the present method is confirmed to be highly sensitive.

\section{Assay determination of ethinyl estradiol and gestodene}

The \%Assay of Ethinyl estradiol and Gestodene in Femovan tablets is $100.6 \%$ and $98.63 \%$, respectively, and are within the specified limits, which confirmed that the developed method could be successfully applied for the assay of pharmaceutical dosage forms, and reported the results in Tables 16, 17, 18, and 19.

\section{Degradation studies}

Upon degradation study, observed that Ethinyl estradiol and Gestodene had undergone degradation under all stress conditions. The calculated \% degraded amount was within the acceptance criteria. It was observed that the drug was more susceptible to photolysis showing the highest degradation. The successful separation of the obtained degradation products from the active pharmaceutical ingredients without any interference confirmed the specificity. Thus, it proved the stable nature of the developed 
method. Presented the acidic, basic, oxidative, thermal, photolytic, and hydrolytic degradation chromatograms in fig. 6, 7, 8, 9, 10, and 11 , respectively. Reported the calculated results for Ethinyl estradiol and Gestodene in tables 20 and 21, respectively.

All the method validation parameters are within the acceptance criteria and assured sufficient precision and accuracy. A good linear relationship was observed in the concentration range of $10-50 \mu \mathrm{g} / \mathrm{ml}$ and $25-125 \mu \mathrm{g} / \mathrm{ml}$ for Ethinyl estradiol and Gestodene, respectively The detection limit for Ethinyl estradiol was found to be $1.399 \mu \mathrm{g} / \mathrm{ml}$ indicating the high sensitivity of the developed method compared to the reported method [6]. The recovery of the analyte was also found to be more than the reported methods $[5,8]$, indicating a high degree of accuracy. The non-interference of the degraded products with the active pharmaceutical ingredients revealed the stabilityindicating nature of the developed method.

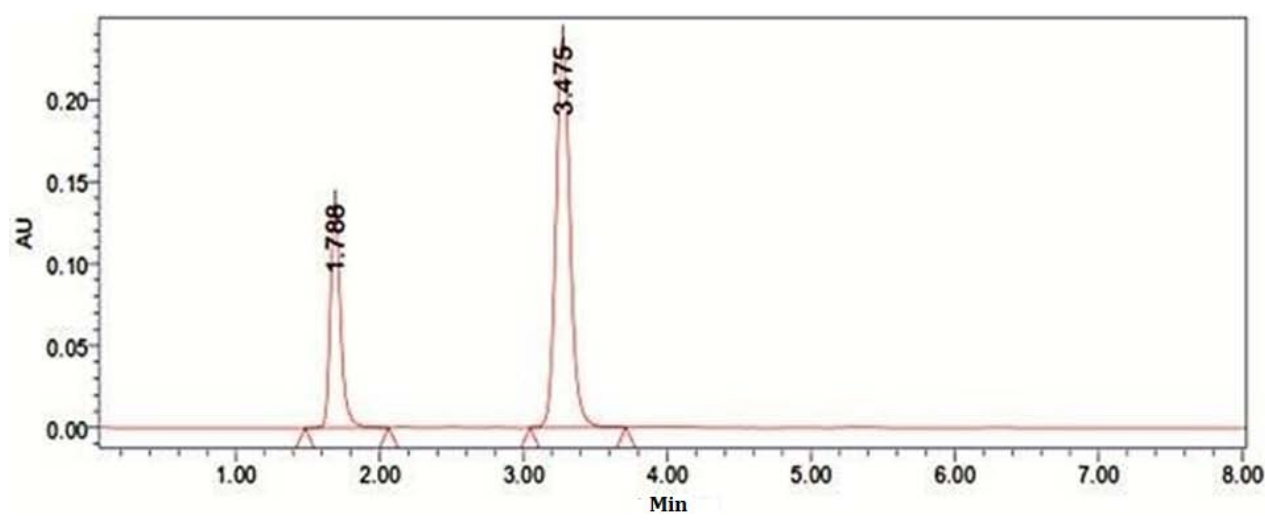

Fig. 3: Optimized chromatogram of ethinyl estradiol and gestodene

Table 1: Optimized chromatogram result

\begin{tabular}{|c|c|c|c|c|c|c|c|}
\hline S. No. & Drug & $\begin{array}{l}\text { Retention time } \\
\text { (min) }\end{array}$ & $\begin{array}{l}\text { Area of the } \\
\text { peak }\end{array}$ & $\begin{array}{l}\text { Height of } \\
\text { the Peak }\end{array}$ & Resolution & $\begin{array}{l}\text { Peak } \\
\text { asymmetry }\end{array}$ & $\begin{array}{l}\text { No. of theoretical } \\
\text { plates }\end{array}$ \\
\hline 1 & Ethinylestradiol & 1.788 & 558647 & 7658 & & 1.26 & 7854 \\
\hline 2 & Gestodene & 3.475 & 7986585 & 48546 & 7.12 & 1.35 & 8865 \\
\hline
\end{tabular}

Table 2: System suitability data of Ethinyl estradiol

\begin{tabular}{|c|c|c|c|c|c|}
\hline Drug & S. No. & Retention time (min) & Analyte response & Theoretical plates(N) & Peak asymmetry \\
\hline Ethinyl & 1 & 1.788 & 558748 & 7854 & 1.26 \\
\hline \multirow[t]{7}{*}{ estradiol } & 2 & 1.792 & 556985 & 7845 & 1.29 \\
\hline & 3 & 1.793 & 557849 & 7896 & 1.28 \\
\hline & 4 & 1.794 & 559865 & 7824 & 1.29 \\
\hline & 5 & 1.791 & 558498 & 7869 & 1.27 \\
\hline & ${ }^{*}$ Mean $(n=5)$ & & 558389 & & \\
\hline & $\pm \mathrm{SD}(\mathrm{n}=5)$ & & 1070.298 & & \\
\hline & $\% \operatorname{RSD}(n=5)$ & & 0.191676 & & \\
\hline
\end{tabular}

*Mean of five determinations, SD: Standard Deviation, RSD: Relative Standard Deviation

Table 3: System suitability data of gestodene

\begin{tabular}{|c|c|c|c|c|c|c|}
\hline Drug & S. No. & Retention time (min) & Area of the peak & No. of theoretical plates & Peak asymmetry & Resolution \\
\hline \multirow[t]{8}{*}{ Gestodene } & 1 & 3.438 & 7986952 & 8856 & 1.36 & 7.13 \\
\hline & 2 & 3.446 & 7958484 & 8874 & 1.32 & 7.14 \\
\hline & 3 & 3.444 & 7986958 & 8896 & 1.39 & 7.15 \\
\hline & 4 & 3.440 & 7984874 & 8874 & 1.34 & 7.16 \\
\hline & 5 & 3.442 & 7986989 & 8859 & 1.38 & 7.15 \\
\hline & $*$ Mean $(n=5)$ & & 7980851 & & & \\
\hline & $\pm \mathrm{SD}(\mathrm{n}=5)$ & & 12536.55 & & & \\
\hline & $\% \operatorname{RSD}(n=5)$ & & 0.157083 & & & \\
\hline
\end{tabular}

*Mean of five determinations, SD: Standard Deviation, RSD: Relative Standard Deviation

Table 4: Linearity data of ethinylestradiol

\begin{tabular}{ll}
\hline Concentration $\boldsymbol{\mu g} / \mathbf{m l}$ & Average peak Area \\
\hline 10 & 253898 \\
20 & 501647 \\
30 & 751256 \\
40 & 985789 \\
50 & 1235898 \\
\hline
\end{tabular}


Linearity curve of ethinyl estradiol

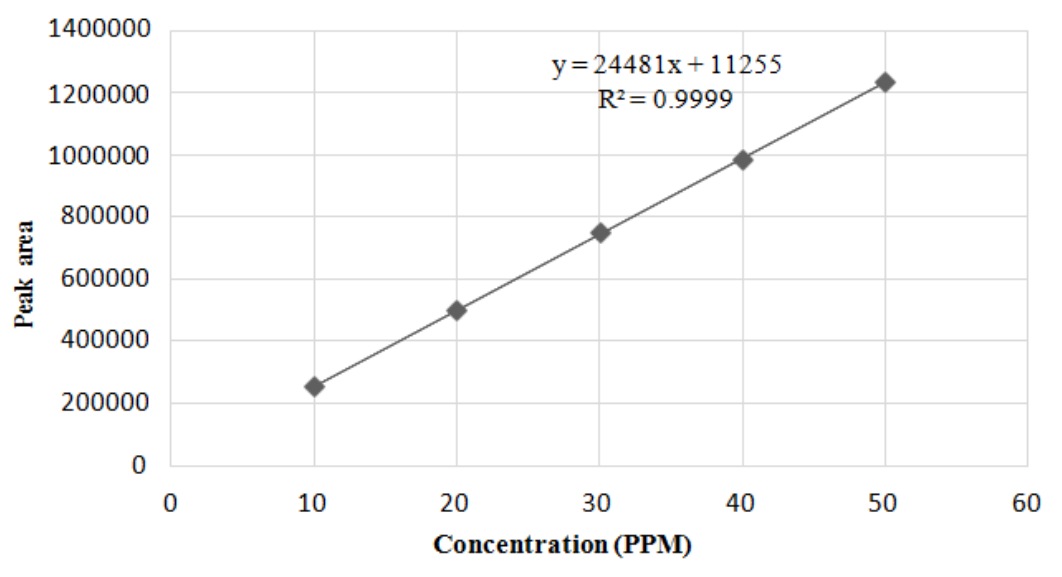

Fig. 4: Linearity plot of Ethinyl estradiol

Table 5: Linearity data of gestodene

\begin{tabular}{ll}
\hline Concentration $\boldsymbol{\mu g} / \mathbf{m l}$ & Average peak area \\
\hline 25 & 3252897 \\
50 & 6316585 \\
75 & 9438787 \\
100 & 12387436 \\
125 & 15365874 \\
\hline
\end{tabular}

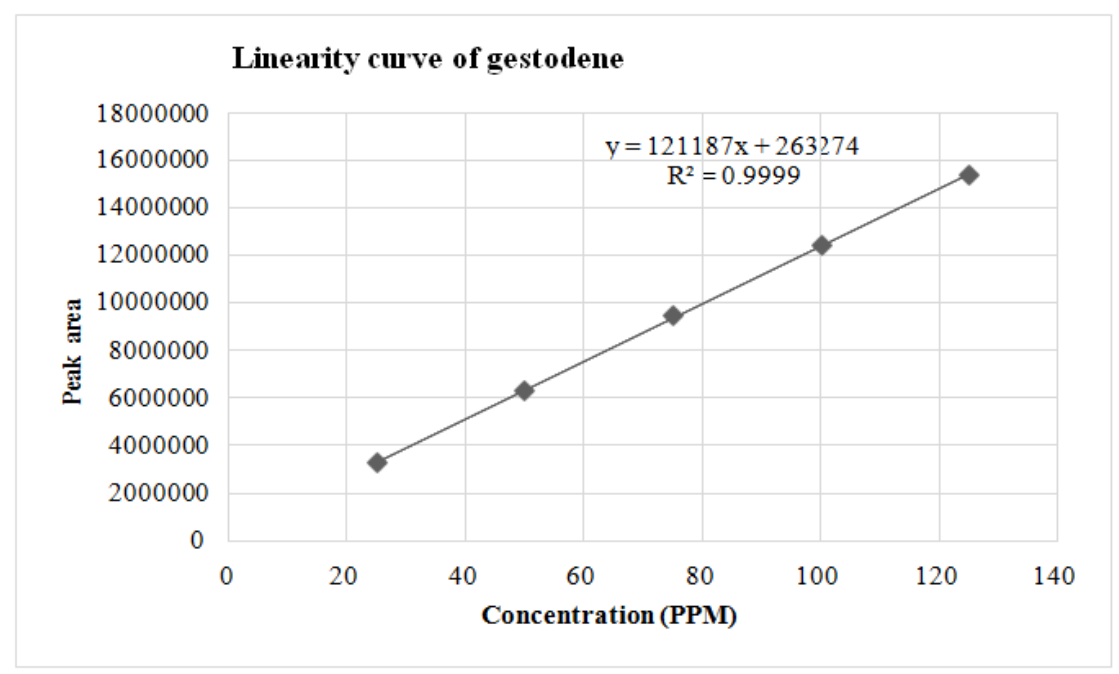

Fig. 5: Linearity plot of gestodene

Table 6: Ethinyl estradiol accuracy data

\begin{tabular}{|c|c|c|c|c|c|c|c|}
\hline Drug & Spiking level & Peak area & $\begin{array}{l}* \text { Average } \\
\text { area }(n=3)\end{array}$ & $\begin{array}{l}\text { Amount added } \\
(\mu \mathrm{g} / \mathrm{ml})\end{array}$ & $\begin{array}{l}\text { Amount obtained } \\
(\mu \mathrm{g} / \mathrm{ml})\end{array}$ & $\begin{array}{l}\text { *Percentage } \\
\text { recovery }\end{array}$ & $\begin{array}{l}\text { Average recovery } \\
(n=9)\end{array}$ \\
\hline \multirow[t]{3}{*}{ estradiol } & $50 \%$ & $\begin{array}{l}253848 \\
252856 \\
253874\end{array}$ & 253526 & 10 & 9.89 & $98.9 \%$ & $99.84 \%$ \\
\hline & $100 \%$ & $\begin{array}{l}501563 \\
501689 \\
502324\end{array}$ & 501858.67 & 20 & 20.04 & $100.2 \%$ & \\
\hline & $150 \%$ & $\begin{array}{l}748584 \\
749897 \\
748468\end{array}$ & 748983 & 30 & 30.13 & $100.43 \%$ & \\
\hline
\end{tabular}

*Mean of three determinations 
Table 7: Gestodene accuracy data

\begin{tabular}{|c|c|c|c|c|c|c|c|}
\hline Drug & $\begin{array}{l}\text { Spiking } \\
\text { level }\end{array}$ & Peak area & $\begin{array}{l}* \text { Average } \\
\text { area }(n=3)\end{array}$ & $\begin{array}{l}\text { Amount added } \\
(\mu \mathrm{g} / \mathrm{ml})\end{array}$ & $\begin{array}{l}\text { Amount found } \\
(\mu \mathrm{g} / \mathrm{ml})\end{array}$ & $\begin{array}{l}\text { *Percentage recovery } \\
(\mathrm{n}=3)\end{array}$ & $\begin{array}{l}\text { Average recovery } \\
(n=9)\end{array}$ \\
\hline \multirow[t]{3}{*}{ Gestodene } & $50 \%$ & $\begin{array}{l}3314535 \\
3312453 \\
3318542\end{array}$ & 3315176.67 & 25 & 25.183 & $100.7 \%$ & $99.92 \%$ \\
\hline & $100 \%$ & $\begin{array}{l}6287487 \\
6279654 \\
6286475\end{array}$ & 6284538.67 & 50 & 49.68 & $99.37 \%$ & \\
\hline & $150 \%$ & $\begin{array}{l}9328748 \\
9315462 \\
9325645\end{array}$ & 9323285 & 75 & 74.76 & $99.68 \%$ & \\
\hline
\end{tabular}

*Mean of three determinations

Table 8: Repeatability data of Ethinyl estradiol

\begin{tabular}{llllll}
\hline Drug & Injection & Retention time (min) & Peak area & No. of theoretical plates \\
\hline Ethinyl & 1 & 1.789 & 558748 & 7896 & Peak asymmetry \\
estradiol & 2 & 1.780 & 558698 & 7845 & 1.26 \\
& 3 & 1.790 & 558475 & 7892 & 1.28 \\
& 4 & 1.791 & 558698 & 7849 & 1.27 \\
& 5 & 1.792 & 558265 & 7829 & \\
& $*$ Mean (n=5) & & 558576.8 & & \\
& \#SD (n=5) & & 203.8816 & & \\
& \%RSD (n=5) & & 0.0365 & & \\
\hline
\end{tabular}

*Mean of five determinations, SD: Standard Deviation, \%RSD: Relative Standard Deviation

Table 9: Repeatability data of gestodene

\begin{tabular}{llllll}
\hline Drug & Injection & Retention time (min) & Peak area & No. of theoretical plates & Peak asymmetry \\
\hline Gestodene & 1 & 3.408 & 7986985 & 8856 & 1.36 \\
& 2 & 3.414 & 7985487 & 8849 & 1.37 \\
& 3 & 3.419 & 7985468 & 8874 & 1.39 \\
& 4 & 3.428 & 7968547 & 8957 & 1.38 \\
& 5 & 3.435 & 7982564 & 8965 & \\
& $*$ Mean (n=5) & & 7981810 & & \\
& ISD (n=5) & & 7585.473 & & \\
& \%RSD (n=5) & & 0.095034 & & \\
\hline
\end{tabular}

*Mean of five determinations, SD: Standard Deviation, \%RSD: Relative Standard Deviation

Table 10: Day 1 Intermediate precision data of ethinylestradiol

\begin{tabular}{lllll}
\hline Drug & Injection & Retention time (min) & Peak area & No. of theoretical plates \\
\hline Ethinyl & 1 & 1.792 & 558965 & 7859 \\
estradiol & 2 & 1.789 & 558476 & 7895 \\
& 3 & 1.787 & 558947 & 7829 \\
& $*$ Mean $(\mathrm{n}=3)$ & & 558796 & 1.29 \\
& \pm SD $(\mathrm{n}=3)$ & & 277.2742 & 1.27 \\
& \%RSD (n=3) & & 0.04962 & \\
\hline
\end{tabular}

*Mean of three determinations, SD: Standard Deviation, \%RSD: Relative Standard Deviation

Table 11: Day 1 Intermediate precision data of gestodene

\begin{tabular}{|c|c|c|c|c|c|}
\hline Drug & Injection & Retention time (min) & Peak area & No. of theoretical plates & Peak asymmetry \\
\hline \multirow{6}{*}{ Gestodene } & 1 & 3.435 & 7986986 & 8849 & 1.38 \\
\hline & 2 & 3.477 & 7985985 & 8879 & 1.37 \\
\hline & 3 & 3.482 & 7898654 & 8896 & 1.39 \\
\hline & *Mean $(\mathrm{n}=3)$ & & 7957208 & & \\
\hline & $\pm S D(n=3)$ & & 50712.01 & & \\
\hline & $\% \operatorname{RSD}(n=3)$ & & 0.637309 & & \\
\hline
\end{tabular}

*Mean of three determinations, SD: Standard Deviation, \%RSD: Relative Standard Deviation

Table 12: Day 2 Intermediate precision data of ethinyl estradiol

\begin{tabular}{lllll}
\hline Drug & Injection & Retention time (min) & Peak area & No. of theoretical plates \\
\hline Ethinyl & 1 & 1.793 & 568965 & 7989 \\
estradiol & 2 & 1.789 & 569854 & 7986 \\
& 3 & 1.790 & 569878 & 7994 \\
& *Mean (n=3) & & 569565.7 & \\
& \pm SD (n=3) & & 520.331 & \\
& \%RSD (n=3) & & 0.091356 & \\
\hline
\end{tabular}

*Mean of three determinations, SD: Standard Deviation, \%RSD: Relative Standard Deviation 
Table 13: Day 2 Intermediate precision data of gestodene

\begin{tabular}{lllll}
\hline Drug & Injection & Retention time (min) & Peak area & No. of theoretical plates \\
\hline Gestodene & 1 & 3.478 & 8045652 & 8987 \\
& 2 & 3.473 & 8065879 & 8959 \\
& 3 & 3.474 & 8075847 & 8937 \\
& $*$ Mean (n=3) & & 8062459 & 1.38 \\
& \pm SD (n=3) & & 15385.22 & \\
& \%RSD & 0.190825 & \\
\hline
\end{tabular}

*Mean of three determinations, SD: Standard Deviation, \%RSD: Relative Standard Deviation

Table 14: Robustness data of ethinyl estradiol

\begin{tabular}{|c|c|c|c|c|c|}
\hline \multicolumn{2}{|c|}{ Slightly changed parameters } & \multirow{2}{*}{$\begin{array}{l}\text { Peak area } \\
558647\end{array}$} & \multirow{2}{*}{$\begin{array}{l}\text { Retention time (min) } \\
1.788\end{array}$} & \multirow{2}{*}{$\begin{array}{l}\text { No. of theoretical plates } \\
7854\end{array}$} & \multirow{2}{*}{$\begin{array}{l}\text { Peak asymmetry } \\
1.26\end{array}$} \\
\hline Flow rate & 1.0 & & & & \\
\hline \multirow[t]{2}{*}{$(\mathrm{ml} / \mathrm{min})$} & 0.9 & 636589 & 1.867 & 7978 & 1.27 \\
\hline & 1.1 More flow rate of $0.9 \mathrm{ml} / \mathrm{min}$ & 535685 & 1.744 & 7576 & 1.39 \\
\hline$\%$ of & 20 & 548576 & 1.831 & 7367 & 1.37 \\
\hline Acetonitrile & 30 & 525874 & 1.874 & 7296 & 1.28 \\
\hline
\end{tabular}

Table 15: Robustness study data of gestodene

\begin{tabular}{lllll}
\hline \multicolumn{2}{l}{ Slightly changed parameters } & Peak area & Retention time (min) & No. of theoretical plates \\
\hline Flow rate & 1.0 & 7986585 & 3.475 & 8865 \\
(ml/min) & 0.9 & 8265847 & 3.724 & 9152 \\
& 1.1 & 7658745 & 3.097 & 8685 \\
\% Acetonitrile & 20 & 7758498 & 6.242 & 8475 \\
& 30 & 7659854 & 2.402 & 8369 \\
\hline
\end{tabular}

Table 16: Assay data of Ethinyl estradiol standard

\begin{tabular}{|c|c|c|c|c|c|}
\hline Drug & Injection & Retention time (min) & Peak area & No. of theoretical plates & Peak asymmetry \\
\hline Standard & 1 & 1.791 & 558698 & 7854 & 1.26 \\
\hline Ethinyl & 2 & 1.794 & 558674 & 7822 & 1.28 \\
\hline \multirow[t]{6}{*}{ estradiol } & 3 & 1.793 & 558694 & 7895 & 1.29 \\
\hline & 4 & 1.792 & 558748 & 7826 & 1.27 \\
\hline & 5 & 1.788 & 558962 & 7849 & 1.26 \\
\hline & ${ }^{*}$ Mean $(\mathrm{n}=5) 0$ & & 558755.2 & & \\
\hline & $\pm \operatorname{SD}(\mathrm{n}=5)$ & & 118.7737 & & \\
\hline & $\% \operatorname{RSD}(n=5)$ & & 0.021257 & & \\
\hline
\end{tabular}

*Mean of five determinations, SD: Standard Deviation, \%RSD: Relative Standard Deviation

Table 17: Assay data of gestodene standard

\begin{tabular}{|c|c|c|c|c|c|c|}
\hline Drug & Injection & Retention time (min) & Peak area & No. of theoretical plates & Peak asymmetry & Resolution \\
\hline Gestodene & 1 & 3.442 & 7986852 & 8857 & 1.36 & 7.15 \\
\hline \multirow[t]{7}{*}{ standard } & 2 & 3.440 & 7985685 & 8874 & 1.34 & 7.14 \\
\hline & 3 & 3.444 & 7984573 & 8892 & 1.35 & 7.16 \\
\hline & 4 & 3.446 & 7986365 & 8849 & 1.39 & 7.15 \\
\hline & 5 & 3.438 & 7989856 & 8825 & 1.35 & 7.18 \\
\hline & *Mean $(n=5)$ & & 7986666 & & & \\
\hline & $\pm \mathrm{SD}(\mathrm{n}=5)$ & & 1977.644 & & & \\
\hline & $\%$ RSD $(n=5)$ & & 0.024762 & & & \\
\hline
\end{tabular}

*Mean of five determinations, SD: Standard Deviation, \%RSD: Relative Standard Deviation

Table 18: Assay data of ethinyl estradiol sample

\begin{tabular}{lllll}
\hline Drug & Injection & Retention time (min) & Peak area & No. of theoretical plates \\
\hline Ethinyl & 1 & 1.791 & 562453 & 7965 \\
estradiol & 2 & 1.791 & 563124 & 7982 \\
Sample & 3 & 1.794 & 563256 & 7985 \\
& $*$ Mean (n=3) & & 562944.33 & \\
& \pm SD (n=3) & & 430.59 & \\
& \%RD (n=3) & 0.076 & \\
\hline
\end{tabular}

*Mean of three determinations, SD: Standard Deviation, \%RSD: Relative Standard Deviation 
Table 19: Assay data of gestodene sample

\begin{tabular}{lllll}
\hline Drug & Injection & Retention time (min) & Peak area & No. of theoretical plates \\
\hline Gestodene & 1 & 3.434 & 8012432 & 7264 \\
sample & 2 & 3.442 & 8023654 & 7285 \\
& 3 & 3.440 & 8012543 & 7293 \\
& *Mean (n=3) & & 8016209.67 & \\
& \pm SD (n=3) & & 6447.22 & \\
& \%RSD (n=3) & & 0.08 & 1.38 \\
\end{tabular}

*Mean of three determinations, SD: Standard Deviation, \%RSD: Relative Standard Deviation

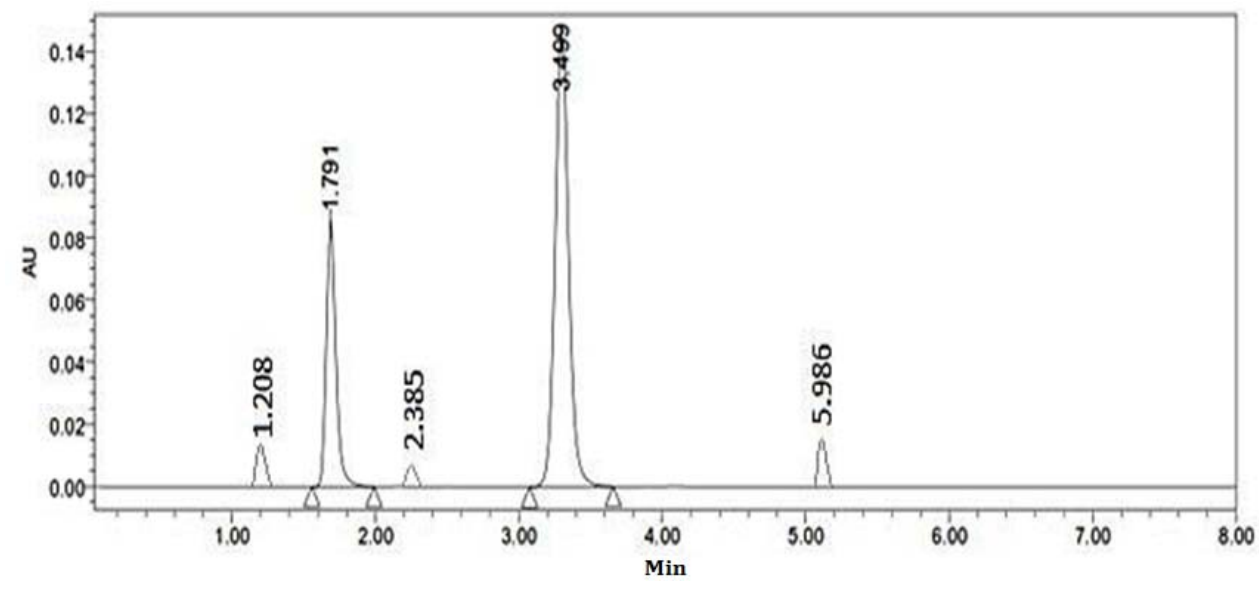

Fig. 6: Ethinylestradiol and Gestodene acidic degradation chromatogram

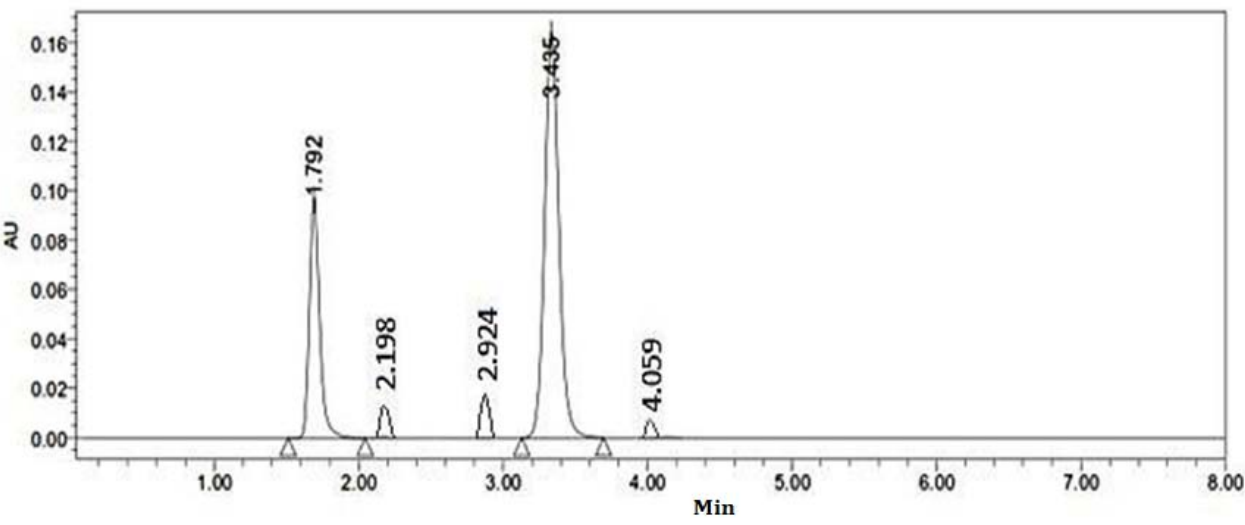

Fig. 7: Ethinyl estradiol and gestodene alkaline degradation chromatogram

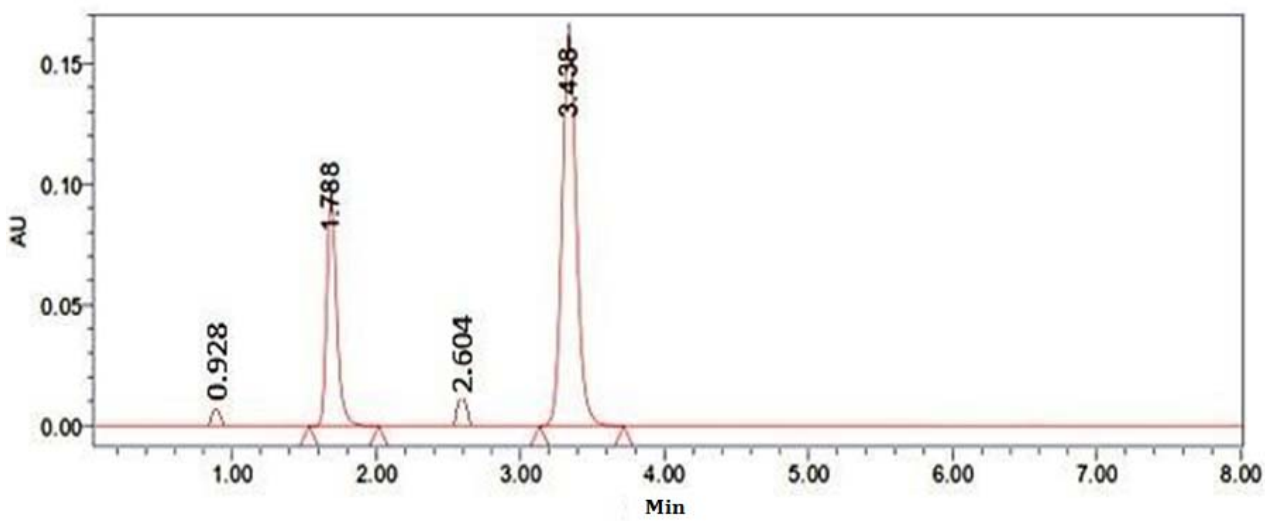

Fig. 8: Ethinyl estradiol and gestodene oxidative degradation chromatogram 


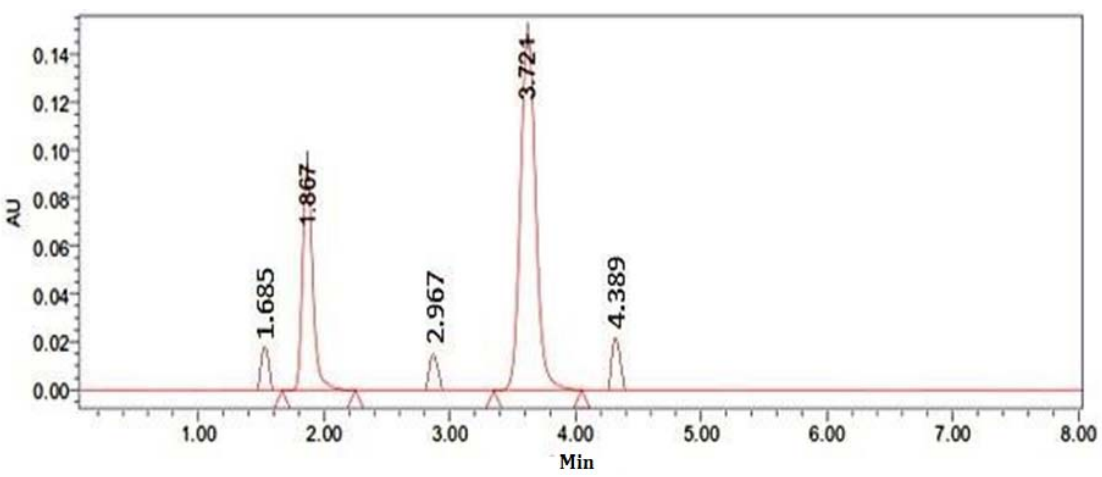

Fig. 9: Ethinylestradiol and gestodene thermal degradation chromatogram

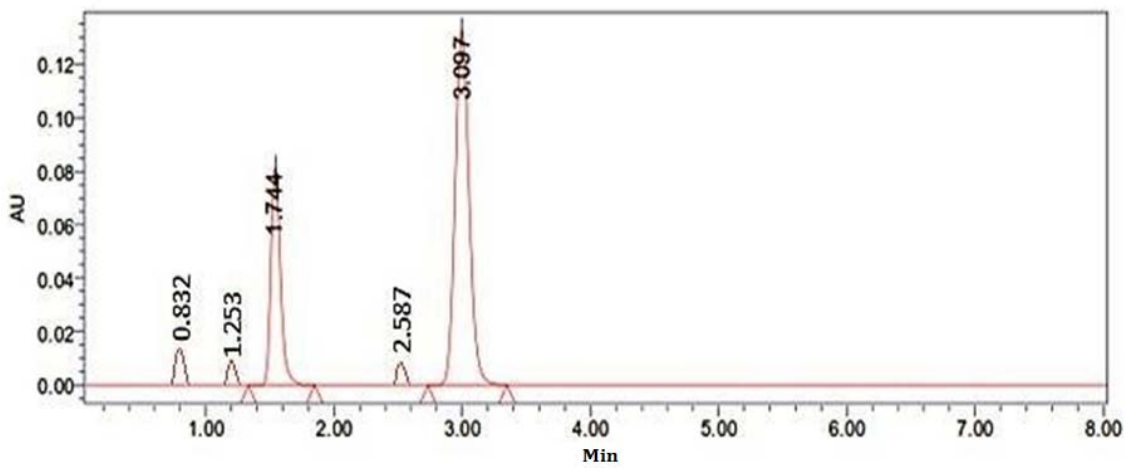

Fig. 10: Ethinyl estradiol and gestodene photolytic degradation chromatogram

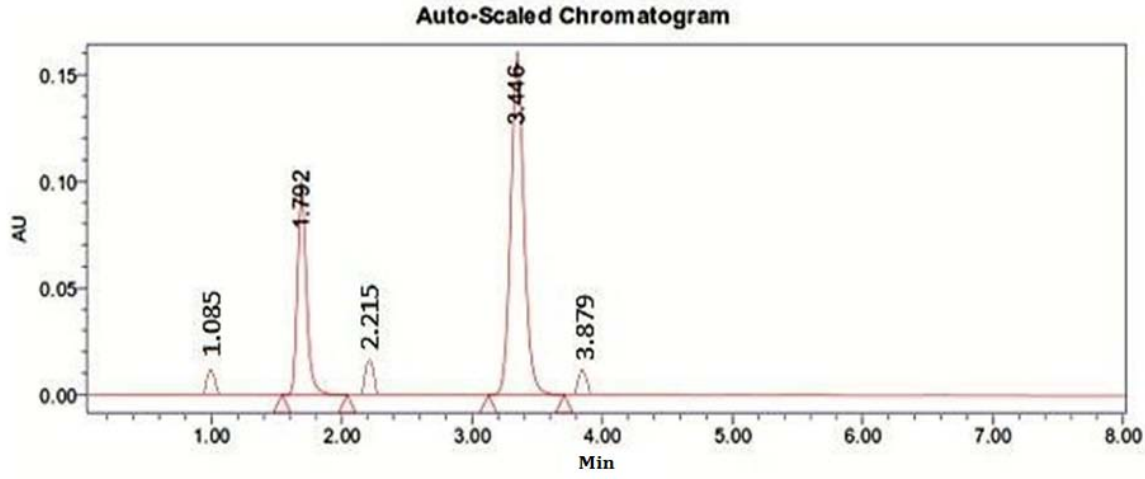

Fig. 11: Ethinyl estradiol and gestodene hydrolytic degradation chromatogram

Table 20: Forced degradation studies data for Ethinyl estradiol

\begin{tabular}{llllll}
\hline S. No. & Stress condition & Peak area & \% of degraded amount & \% of active amount & Total \% of amount \\
\hline 1 & Standard & 558647 & 0 & $100 \%$ & $100 \%$ \\
2 & Acidic & 476693.48 & 14.67 & 85.33 & $100 \%$ \\
3 & Basic & 515351.85 & 7.75 & 92.25 & $100 \%$ \\
4 & Oxidative & 497307.55 & 10.98 & 89.02 & $100 \%$ \\
5 & Thermal & 486413.94 & 12.93 & 87.07 & $100 \%$ \\
6 & Photolytic & 395186.88 & 29.74 & 70.74 & $100 \%$ \\
7 & Water & 491832.81 & 11.96 & 88.04 & $100 \%$ \\
\hline
\end{tabular}

Table 21: Forced degradation studies data for gestodene

\begin{tabular}{|c|c|c|c|c|c|}
\hline S. No. & Stress condition & Peak area & \% of degraded amount & $\%$ of active amount & Total \% of amount \\
\hline 1 & Standard & 7986585 & 0 & $100 \%$ & $100 \%$ \\
\hline 2 & Acidic & 6733489.81 & 15.69 & 84.31 & $100 \%$ \\
\hline 3 & Basic & 7271785.64 & 8.95 & 91.05 & $100 \%$ \\
\hline 4 & Oxidative & 7032188.09 & 11.05 & 88.05 & $100 \%$ \\
\hline 5 & Thermal & 6880442.98 & 13.85 & 86.15 & $100 \%$ \\
\hline 6 & Photolytic & 5154541.96 & 35.46 & 64.54 & $100 \%$ \\
\hline 7 & Hydrolysis & 7108859.31 & 10.99 & 89.01 & $100 \%$ \\
\hline
\end{tabular}




\section{CONCLUSION}

The established present method revealed that it is simple, selective, specific, and can generate accurate and precise results. Moreover, the shorter duration of analysis time and lesser mobile phase consumption confirmed that the method is rapid and economical. The successful separation of the forced degradation products from the active pharmaceutical ingredients without any interference confirmed the stability-indicating nature of the developed method. Hereupon, the present method can be satisfactorily applied for the routine laboratory simultaneous estimation of Ethinyl estradiol and Gestodene.

\section{ACKNOWLEDGEMENT}

We are grateful to Sura Labs, Hyderabad, for supplying the Ethinyl estradiol and Gestodene standard drugs as gift samples to carry out the research work.

\section{FUNDING}

Nil

\section{AUTHORS CONTRIBUTIONS}

We declare that the author's present work was done and is an original work. D. Suchitra has carried out the research work. Professor Battu Satyanarayana guided, proofread the manuscript, suggested the necessary corrections, and helped in writing the manuscript.

\section{CONFLICT OF INTERESTS}

\section{Declared none}

\section{REFERENCES}

1. https://en.m.wikipedia.org/wiki/Ethinylestradiol [Last accessed on 10 Feb 2021]

2. https://pubchem.ncbi.nlm.nih.gov/compound/Ethinylestradiol [Last accessed on 10 Feb 2021]

3. https://en.m.wikipedia.org/wiki/Gestodene [Last accessed on 10 Feb 2021]
4. https://pubchem.ncbi.nlm.nih.gov/compound/Gestodene [Last accessed on 10 Feb 2021]

5. Kanchan Nautiyal, Ramakrishna K. Analytical method development and validation for simultaneous determination and quantification of ethinyl estradiol and gestodene in combined tablet dosage form by RP-HPLC. J Chem Pharm Sci 2014;6:74-80.

6. Aleksandra Laban, Slavko Markovic, Milena Stankov, Predrag Djurdjevic. Simultaneous determination of gestodene and ethinyl estradiol in contraceptive formulations by RP-HPLC. Anal Lett 2004;37:273-82.

7. Xiong Z, Sun X, Huo T, Li N, Zheng Y, Sun Y. Development and validation of UPLC-MS/MS method for simultaneous determination of gestodene and ethinyl estradiol in rat plasma. Biomed Chromatogr 2010;24:160-8.

8. Kishore Kumar I, Jayaprakash P, Sivannarayana Reddy V, Sriramulu J. A stability-indicating high-performance liquid chromatographic method for separation and quantification of impurities in ethinylestradiol and gestodene tablets. J Pharm Biol 2017;7:33-40.

9. Praveen C, Ranganath MK, Divakar P. Method development and validation for simultaneous estimation of ethinyl estradiol and drospirenone and forced degradation behavior by HPLC in the combined dosage form. Pharm Anal Acta 2013;4:1-5.

10. ICH, Q2B-Validation of Analytical procedures; Methodology International Conference on Harmonization; 1996.

11. International Conference on Harmonization, ICH Q1 A [R2]; Stability Testing of New Drug substances and products; 2003.

12. Snyder LR, Kirkland JJ, Glajch JL. Practical HPLC method development. $2^{\text {nd }}$ ed. Hoboken: John Wiley and Sons, Inc; 1997.

13. Vikas Kumar Pal, Yogendra Pal. Analytical method development and method validation for determination assay and content uniformity of levonorgestrel by reversed-phase high-performance liquid chromatography. Asian J Pharm Clin Res 2020;13:101-7.

14. Majan Naim, Aejaz Ahmed, Khan GJ. Stability indicating reversephase High-Performance liquid chromatography method development and validation for simultaneous estimation of Telmisartan and Benidipine hydrochloride in the pharmaceutical dosage form. Asian J Pharm Clin Res 2018;11:342-50. 